\title{
The Return of Fiscal Policy and the Euro Area Fiscal Rule
}

\author{
Vítor Constâncio ${ }^{1}$
}

Published online: 6 July 2020

() Association for Comparative Economic Studies 2020

\begin{abstract}
The text describes the theoretical developments of the assignment rules regarding fiscal and monetary policies and the respective roles in macroeconomics stabilisation. Monetary policy emerged as the dominant policy, reducing the active macrorole of fiscal policy to taking care of debt sustainability. This consensus started to change, and a new view has appeared, giving a more active role to fiscal policy. The article concludes with a brief analysis of fiscal rules, followed by a discussion about the European Union fiscal framework, and its necessary revision.
\end{abstract}

Keywords Fiscal Policy · Fiscal Rules · Monetary Policy · European Monetary Union $\cdot$ EU Stability and Growth Pact

\section{JEL Classification E62 $\cdot \mathrm{E} 63 \cdot \mathrm{E} 42$}

Even before the present intense use of fiscal policy to deal with the social and economic fallout of the coronavirus crisis, fiscal policy had started to undergo a sort of rebirth as a macroeconomic stabilisation tool. The present text was prepared for a Conference last November and is reproduced here with minor adjustments. ${ }^{1}$ During several decades that preceded the present crisis, the mainstream consensus about the stabilisation role of macroeconomic policies has given prominence or even exclusivity to monetary policy, confining fiscal policy to the passive role of pursuing debt sustainability and microeconomic efficiency goals. The exception to this rule came just in short episodes when it was necessary to respond to deep economic shock as

\footnotetext{
${ }^{1}$ This text was the basis for a keynote address at the International Network for Economic Research (INFER) Workshop on "New challenges for fiscal policy" organised by UECE-Research Unit on Complexity and Economics, Lisbon School of Economics and Management (ISEG) on 22 November 2019 at ISEG.
}

Vítor Constâncio was former European Central Bank Vice-President.

Vítor Constâncio

constancio@iseg.ulisboa.pt

1 Lisbon School of Economics and Management (ISEG), Lisbon, Portugal 
it happened between 2008 and 2010. The turn to fiscal consolidation materialised in the July 2010 G20 meeting in Toronto. The way this restrictive policy was implemented in the euro area led to a second dip recession that was only felt in Europe. After that, monetary policy was put again in sole charge of macro-stabilisation policy and had to embark quite unconventional instruments to struggle against low inflation and subdued growth.

In the past few years, though, fiscal policy seems to emerge again as a necessary active policy tool in view of the clear diminishing returns of monetary policy and its visible inability, after 10 years, to place inflation steadily at the consensual target of $2 \%$.

In the remaining text, I will first briefly describe the historical developments around the monetary and fiscal policy macroeconomic roles. Then, I will examine the reasons behind a new view about fiscal policy that has emerged. This will be followed by an analysis of the search for fiscal rules and by a discussion about the European Union fiscal framework and its necessary revision.

After the Second World War, a Keynesian consensus prevailed, giving fiscal policy the dominant role in targeting output stabilisation, whereas monetary policy had a more passive role in view of its suspected low effectiveness. There was even a sort of fiscal dominance of monetary policy with most central banks not being independent and being expected to cooperate with the Treasuries. The first edition of Samuelson's Manual ${ }^{2}$ had a section named "The inadequacies of monetary control of the business cycle" where it was repeated the old saying that "one can take a horse to the water but cannot make him drink". This consensus lasted until the midsixties when criticism of fiscal policy started alongside the renewal of monetarism promoted by Friedman. ${ }^{3}$ The inflation increase that began in the late sixties and was magnified by the 1973 oil shock helped the monetarist cause.

In the long dispute between Keynesians and monetarists during the sixties and seventies, the arguments against the effectiveness of fiscal policy were of three types:

(1) First, those related to the slowness of fiscal policy implementation. Long inside lags for tax changes and long outside lags to implement expenditure, especially public investment. This is a genuine problem of fiscal policy that can only be mitigated by keeping a permanent collection of adequate projects.

(2) Crowding-out of private investment and consumer durables as deficits and increasing debt would increase interest rates. A long and dated debate ensued about the elasticities of IS and LM curves and whether or not LM was near vertical. This debate had consequences for the size of fiscal multipliers, a subject that surfaced again after 2008 and that I will address later. It is worth noting that there are many historical episodes where bigger deficits did not induce higher interest rates. That is what happens in situations close to liquidity traps, like the one that occurred after the 2008 crisis.

\footnotetext{
2 See Samuelson (1948).

3 See Friedman (1968).
} 
(3) The third category of arguments was related to consumer behaviour and the reaction to fiscal stimulus. According to the Permanent Income theory of consumption, temporary fiscal expansionary measures could not affect consumers' behaviour as they would react only to their view on their permanent income.

Regarding permanent changes in taxes or expenditures conducive to deficits, the argument came from the Ricardo Equivalence theory, introduced by Barro (1974). It claimed that stimulus financed by bonds would produce no change in consumption. Consumers were assumed to be forward-looking, with a long horizon encompassing the life of their descendants. Therefore, their decisions, on the basis of the present discounted value of their resources, would count with tax increases in the future necessary to repay the issued debt. Consequently, their present consumption would not budge, and they would increase their savings subsequently to the stimulus offsetting its effects. Financing public expenditure by issuing bonds would give the same results as financing them with taxes, deficits did not matter after all. Ricardo, having raised the possibility, wrote that he did not believe it. ${ }^{4}$ There is a lot of empirical evidence against that extreme Ricardian hypothesis as it is predicated on a host of unrealistic assumptions: no liquidity constraints, no myopic horizons, no precautionary saving behaviour, etc. There is also the awareness that a significant part of the debt is not paid up but is rolled over during long periods of time, especially when the debt to GDP ratio is going down.

It should be underlined that, differently from the previous argument, the Ricardian Equivalence argument does not apply in the case of pure temporary stimulus measures, because then tax revenues do not have to be increased forever to deal with it. And the evidence is overwhelming that consumption and output respond to temporary measures in different degrees, according to other economic conditions. Fiscal multipliers are positive.

Notwithstanding the good counterarguments I mentioned, the monetarist criticism of fiscal policy prevailed, and discretionary fiscal policy was progressively abandoned. Authorities still responded to the first 1973 oil shock with fiscal stimulus, but inflation accelerated further, which led to a strong monetary policy reaction. Consequently, the FED implemented big rate increases in 1979-1980 after the second oil shock, creating a recession. So, the 1973 first oil shock helped the monetarist reaction, despite the truth that the oil price increase that aggravated inflation was not a demand/monetary shock but corresponded to a supply shock triggering stagflation.

Since the 1977 seminal paper by Kydland and Prescott, ${ }^{5}$ there was also a drive to introduce in macro policies, rules instead of discretion. This idea provided arguments in favour central banks' independence to foster their credibility so that they could commit to long-term rules.

Another debate in the literature referred to whether there should be cooperation or separation between fiscal and monetary policies and respective responsible authorities. The analysis was very much dependent on assumptions about the market

\footnotetext{
4 See O'Driscoll (1977).

5 See Kydland and Prescott (1997).
} 
imperfections considered and on the model used. In the end, monetary policy gained dominance, more than simple separation, and a new consensus was formed, summed up in the following way by Kirsanova et al. (2009): "The consensus assignment ... refers to the idea that monetary policy should normally focus on business cycle stabilisation and inflation control, while fiscal policy (at the macro level) should focus on the control of government debt or deficits".

The reduction in the fiscal policy stabilisation role attained its culmination with the early DSGE models that assumed total efficiency of monetary policy to place the economy at its economic potential and targeted inflation, just by changing interest rates. This omniscient power resulted in the models from the central role of Euler equations, an inter-temporal optimality condition that links today's level of consumption to expected consumption in the next period and further into the future, responding to any change in the interest rate. The shortcomings of Euler equations have been well documented as, among other things, the interest rate targeted by monetary policy has no relation with the interest rate implicit in the Euler consumption function. ${ }^{6}$ Euler equations have many other flaws as they neither envisage that consumers face idiosyncratic (household-specific) and uninsurable income uncertainty, nor that uncertainty interacts with credit or liquidity constraints. This is in stark contrast to recent research that emphasises the importance of precautionary saving, liquidity constraints, leverage, and heterogeneity, including heterogeneity in marginal propensities to consume. ${ }^{7}$ In practice, we know that monetary policy does not have the divine powers that these models pretend.

On the immediate aftermath of the great financial crisis, the consensual assignment had to be broken, and fiscal policy was strongly activated, if only for just a couple of years. This was also the time when a long debate ensued about the size of fiscal multipliers and their variability according to the economic situation.

A quite well-known survey of multipliers calculated by time-series methods by Ramey (2011) finds expenditure multipliers varying from 0.8 in normal times to 1.5 in economic slowdowns. Using structural models instead from the FED, the EU Commission, the ECB, the IMF, the OECD, and B. of Canada, Coenen et al. (2012) find a range of values between 0.9 and 1.3 which increases if the stimulus is maintained for 2 years and can reach 2.2 when accompanied by accommodative monetary policy. Christiano et al. (2011) with a structural model, even find a multiplier of 3 when monetary policy is at the zero lower bound (ZLB).

Blanchard and Leigh (2013) in an IMF paper explained the errors made in estimating the fiscal multipliers in the context of the first Greek adjustment programme and calculated a posteriori much higher values as it is appropriate in a crisis downturn. The mistake in the multipliers used in the programme led to a much severe GDP drop than what was intended.

DeLong and Summers (2012) by considering the assumptions of hysteresis effects and fiscal multipliers higher than 1 in a liquidity trap of low interest rates

\footnotetext{
${ }^{6}$ On the first point, see Carroll (2001); on the second point, see Canzoneri et al. (2007).

7 See, e.g. Kaplan and Violante (2014), John (2016) and Mian et al. (2013).

8 See Coenen et al. (2012).
} 
demonstrate how fiscal stimulus can lead to a reduction in the debt to GDP ratio rather than to the opposite desired effect. Fatás and Summers (2015) illustrate how excessive consolidation leaves behind permanent effects via hysteresis and can be self-defeating even aggravating the public debt ratio in some cases. Fatás (2018) also illustrates how the GDP impact of fiscal consolidation that leads to a downward revision of potential output can induce more fiscal restraint in what he calls "a fiscal doom loop".

Finally, Auerbach and Gorodnichenko in their 2017 Jackson Hole paper ${ }^{9}$ confirm their 2012 findings ${ }^{10}$ and substantiate high multipliers (above 2) in recessions. Analysing 25 countries, they find cases of fiscal expansions in downturns that reduced the debt to GDP ratio, thus confirming the theoretical possibility. They also show that fiscal multipliers do not differ between low and high indebted countries.

In conclusion, the literature on multipliers has established how fiscal policy is effective, especially in economic slowdowns like the one now ongoing. However, the recent rethinking of the use of fiscal policy has two other motivations.

First, the obvious diminishing returns to expansionary monetary policy after many years of experimenting with unconventional instruments without achieving its inflation targets. Second, the limits of monetary policy that is also constrained in a medium-term perspective in consequence of the secular stagnation that is affecting advanced economies and makes indispensable the use of fiscal policy.

I start with the short-term limitations of monetary policy, going through its different transmission channels. The interest rate channel shows reduced effects as interest rates along all maturities are already very low. The expectations channel cannot by itself significantly move the economy. Consequently, moving to monetary policy regimes of price level targeting or long-term averaging of inflation cannot be effective. In both cases, economic agents cannot be convinced to change behaviour just based on the announcement of new goals. They want to see what are the instruments to achieve them. The forward guidance tool also depends on the weak expectations channel. Attempts to explore the exchange rate channel could only lead to currency wars that are destructive and self-defeating. Unconventional monetary policy was effective to mitigate the crisis and to start a recovery. Quantitative easing (QE) was valuable to lower yields when policy rates were near zero, it still works, but also with visible declining returns because of the present low levels of sovereign bond yields. Finally, negative policy rates should not be used further as they create a stressful situation for financial institutions that may lead to instability and even a reversal of their expansionary effects. This is an important point because several economists defend more negative rates as the solution for stabilisation. In past advanced economies' recessions, interest rates were reduced, usually 3-5 percentage points to prop up the economy. Some economists seem to believe that reducing rates from +6 to $+2 \%$ is the same as lowering rates from zero to $-4 \%$. They argue in favour of penalising cash until it disappears and significant public subsidies

\footnotetext{
${ }^{9}$ See Auerbach and Gorodnichenko (2017).

10 See Auerbach and Gorodnichenko (2012).
} 
to banks. ${ }^{11}$ Indeed, without those odd and controversial subsidies, there would be an eventually continuous reduction in banks' profitability, creating a reduced credit supply, and financial instability.

The deeper negatives rates would also have a host of other problematic effects. They would trigger asset price bubbles; allow zombie firms` survival that would lower productivity; returns pressure on pension schemes that could lead to people increasing savings to protect for old age, thus frustrating the expected increase in demand. To these aspects, we could also add the political economy consequences of the banks starting at a certain point to apply negative rates to retail deposits.

All these points illustrate why monetary policy was not, on the eve of the coronavirus crisis, in a good position to deal with a possible recessionary phase. In any case, both older theory and historical evidence substantiate that monetary policy is very efficient in controlling high inflation but always had limitations in confronting depressed economies and very low inflation.

The fact that monetary policy became, however, quite expansionary is related to a different situation. What central banks had to do was to provide enough liquidity to keep the firms and the economy afloat and to implement securities purchases programmes to normalise their functioning that the crisis shock threatened to impair. The policy goals have been more about rescue and market normalisation than about economic stimulus. The recovery after the health emergency ends will be sluggish and uneven. To make it more robust, additional fiscal stimulus will be necessary because monetary policy will not be in a position to do much more, for the reasons already mentioned.

This reality of monetary policy limitations in particular cases led Bernanke in 2003 to advocate a type of "helicopter money" for Japan ${ }^{12}$ with temporary monetary financing of growing public expenditures. In 2016, ${ }^{13}$ he suggested that the US Congress and the FED could have a joint procedure to authorise the concrete terms of temporary monetary financing. Last August, well-known former central bankers, like Stanley Fisher and Philipp Hildebrand, used this approach to propose the creation by Treasuries of emergency packages of measures, ready to be implemented, but with the central banks deciding the timing and the amounts to be mobilised. ${ }^{14}$

These proposals reflect an acute awareness of the present monetary policy limits and the need for fundamental new thinking about macroeconomic policy. Naturally, these monetary financing proposals could not be applied in the EU without Treaty change, a very unlikely proposition. Another version of "helicopter money" refers to central bank direct distribution of money to every citizen, a difficult proposal to implement ensuring a level playing field, besides the doubts about the legal support for such an operation that belongs clearly to the remit of Governments. In the USA, there are also discussions of monetary financing from the perspective of a highly expansionary fiscal policy promoted by the ideas of the flawed Modern Monetary Theory (MMT).

\footnotetext{
11 See Agarwal and Kimball (2019).

12 See Bernanke (2003).

13 See Bernanke (2016).

14 See Bartsch et al. (2019).
} 
The second dimension of the monetary policy limitations goes deeper than simply the response to short-term recessionary risks. Advanced economies are stuck in a protracted phase of secular stagnation with low growth, low inflation, and low interest rates. Its main feature is precisely the unbalance between the high propensity to save and the lower prospects for investment. Secular stagnation, in this case, refers to the demand-side version promoted by Larry Summers, ${ }^{15}$ that implies a situation of persistent lack of demand. The real equilibrium interest rate that ensures the planned savings-investment balance at full employment may indeed become negative as recent estimates for the advanced economies indicate. ${ }^{16}$ Rachel and Summers (2019) show the continuous decline of the equilibrium rate in the OECD advanced countries since 1971. ${ }^{17}$

They conclude that: "neutral real interest rates have declined by at least 300 basis points over the last generation.... We highlight the levels of government debt, the extent of pay-as-you-go old age pensions and the insurance value of government health care programs have all ceteris paribus operated to raise neutral real rates.... we suggest that the "private sector neutral real rate" may have declined by as much as 700 basis points since the 1970s. Our findings support the idea that absent offsetting policies, mature industrial economies are prone to secular stagnation. This raises profound questions about stabilisation policy going forward".

It is therefore likely that for a protracted time, advanced countries will have to implement higher deficits, near zero interest rates (hopefully not negative), and try "finding structural policies that promote investment and reduce saving".

There are several structural causes for the unbalance between planned savings and investment, reflecting lack of aggregate demand, like demographic developments, technological shifts towards lower priced investments, income inequality, risk aversion, and consequent increase in risk premia ....

While all these factors create obstacles for the economy to reach potential, there are also supply-side structural factors, underlined by Robert Gordon in a series of papers $^{18}$ that contribute to the low growth of potential output itself. The two broad frameworks about secular stagnation are therefore not mutually exclusive. One emphasises supply-side factors that lower potential growth while the other points at the chronic weakness in demand as the root cause of secular stagnation. The fact that prices are not buoyantly increasing as it would be the case of supply insufficiency suggests that lack of demand is the prevailing factor. However, demand and supply factors may reinforce each other because a chronic weakness in demand would amplify and exacerbate supply constraints as, for instance, the fact that persistent

\footnotetext{
15 See Summers (2016).

16 The concept of a "natural" real interest rate is a controversial one and both Keynes and Friedman did not accept it (see Constâncio 2016).

17 For other estimates see Brand and Mazeli (2019, Holston et al. (2017) and Hamilton et al. (2016).

18 See Gordon $(2012,2014,2016)$.
} 
unemployment may hamper workers' set of skills, thereby curtailing the productive capacity of the economy. ${ }^{19}$

The important point to underline here is that secular stagnation undermines the role of monetary policy as an answer to low growth and low inflation. This implies that fiscal policy must, in the future play a more active role. If the private sector wants to save more than spend in real investment, either a current account surplus develops and/or interest rates get lower, and asset prices tend to rise. The alternative then is for the government to go into deficit, dissaving to offset private "excess" saving. This would increase deficits and the supply of government bonds, which would also lead to higher interest rates, including the real equilibrium rate in a normal nonRicardian world. A smaller current account surplus would also be achieved. The euro area has kept over the past few years a surplus well above the Chinese one. A fiscal stimulus would thus solve several problems at once, including the necessary increase in safe assets that, in view of the regretful absence of a European safe asset, would start to repair the acute scarcity of such securities that is affecting financial stability. The reduction in a very large current account surplus would also avoid possible hostile retaliatory reactions from other countries, especially from the USA.

The prevailing low interest rates that secular stagnation says will continue for the foreseeable future offer support for additional fiscal space. Blanchard (2019) in his AEA lecture, highlighted how the very low rates contribute to mitigate or even eliminate the budget deficit consequences, both on the debt ratio to GDP and the welfare costs of higher public debt. This is the result of the average risk-free rate paid by sovereigns being below the rate of GDP growth. This has happened in significant periods during the recent decades in the USA and other advanced countries. Since the sixties that inequality prevailed, on average, $50 \%$ of the time in OECD countries.

Blanchard is cautious not to draw imprudent recommendations for future fiscal policy despite secular stagnation pointing to a long period of low rates. ${ }^{20}$ Financial markets seem to agree, judging by the embedded expectations of low rates up to 30 years!

On the other hand, there is the possibility that an exaggeration of the primary deficit and the debt could lead to a sudden upward revision of yields, changing their relationship with the growth rate. This means that very high debt ratios, some above $100 \%$, did not cease to be a potential problem all of a sudden. However, the prospect of a prolonged period of low rates does provide some easing of concerns with the debt, at the moment when fiscal policy is called to perform a more substantial role in our economies.

This perspective does not imply that fiscal rules should be abandoned as, in general, they are necessary to counter the "deficit bias" tendency that has many causes, from electoral competition to informational problems or to time inconsistency behaviour. ${ }^{21}$ In a monetary union, there are additional reasons for the existence of such rules in order to avoid countries free riding and to control undesirable externalities. These include both the negative spillovers from possible high debt having to

\footnotetext{
${ }^{19}$ See Blanchard and Summers (1986).

${ }^{20}$ On the caution perspective about fiscal space, see Mehrotra (2017).

${ }^{21}$ See Calmfors and Wren-Lewis (2011).
} 
be restructured in a member country and to demand externalities from fiscal policy that have become even more relevant when interest rates are at the effective lower bound.

A good fiscal rule should take these externalities into account and cater for two main goals: (1) restrain "deficit bias" to avoid excessive debt accumulation; (2) allow public finance to play a macroeconomic stabilisation role as a shock absorber, especially when monetary policy is constrained or when countries are members of monetary union and lost their own monetary policy. There are also other arguments, unrelated to macroeconomic stabilisation or monetary unions that justify the use of deficits and debt as shock absorbers. I am referring to the mainstream optimising analysis of tax smoothing, which recommends the mitigation of tax volatility to minimise their burden over time. ${ }^{22}$ This tax smoothing argument implies, for instance, that after negative shocks, the debt ratio to GDP should adjust down very gradually. However, I will not dwell further on this subject.

What is relevant, regarding the present European fiscal rules, is that they do not appropriately acknowledge the two aspects involved in fiscal policy exerting a shockabsorbing role. First, there is not sufficient recognition embedded in the rules themselves, of situations where monetary policy is particularly constrained and limited, as it is presently the case. Second, the fiscal rule - the Stability Pact—is unbalanced in not allowing sufficient room for the stabilisation role of fiscal policy in member countries, making it procyclical at the euro area level.

That procyclical bias can be illustrated in a simple way, e.g. by comparing from 2000 to 2018, the evolution of the output gap with the cyclical adjusted primary budget balance (see Fig. 1).

Contrasting with fiscal policy in the US, in the euro area, the primary structural balance, became positive since 2011 while the output gap stayed quite negative. The double dip in growth in the EA was mostly due to the coordinated fiscal consolidation in EA country members implemented from 2011 to 2013. Simulations with the EU Commission model Quest show that fiscal policy contributed to cumulative GDP deviations from the baseline scenario that vary by country from 8 to $18 \%{ }^{23}$ Given the new perspectives concerning fiscal policy, we need in Europe to undergo a conceptual change and promote the revision of our procyclical fiscal framework. For a lasting resilience of the euro area, we must have a better way of dealing with cyclical adjustment in our economies. The time has arrived to start discussing the revision of the Stability Pact to achieve a better balance between its two objectives of controlling the debt externality among member countries and allowing a proper stabilisation role for fiscal policy. Both goals are important in a monetary union.

A fiscal rule can be designed around norms for the debt, the deficit or the expenditure path. The present European rule uses all three, in a maze of rigid quantitative targets and exceptions that require a Vade Mecum with more than 200 pages

22 See Barro (1979), Portes and Wren-Lewis (2015) and Begnigno and Woodford (2004).

23 See Jan in 't Veld (2013); see also Rannenberg et al. (2015). 


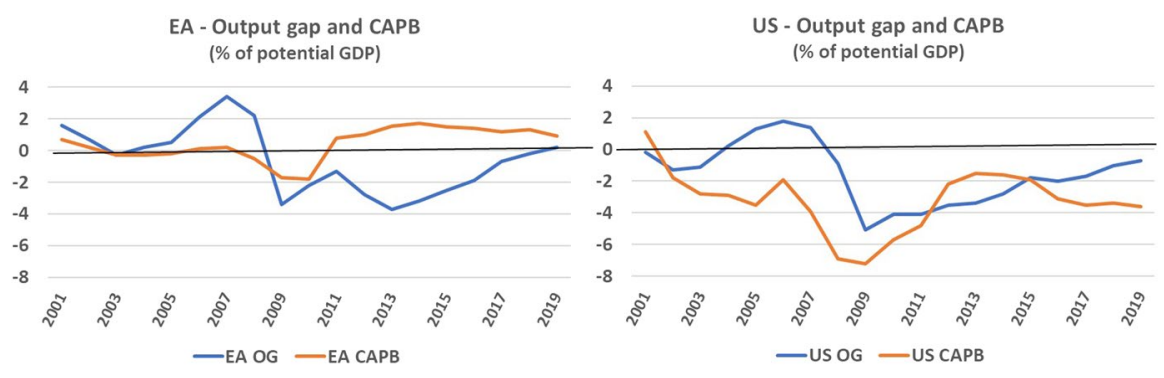

Fig. 1 Fiscal Policy stance in EA and US

to explain it. ${ }^{24}$ It is too complex, difficult to manage and enforce as it is open to contradictory commands. Also, the rules became more intrusive, creating the potential for political tensions, as we saw several times. The independent European Fiscal Board assessed that the Pact has "overlapping fiscal requirements that occasionally offer conflicting signals: a structural adjustment and a target for debt reduction." and "policies are monitored using a multitude of indicators, which inevitably cause conflicting signals" ${ }^{25}$ Sometimes, these conflicts make impossible the full use of the automatic stabilisers as countries are subject to quantitative targets for the debt, for two concepts of deficit (one nominal, another structural), for expenditure growth and for annual targets regarding progress towards debt and the medium-term structural deficit objective.

During the crisis, in 2009, Germany changed its 40-year-old constitutional law that had introduced the "golden rule" allowing deficits equal to investment expenditure, with a new law establishing that the maximum structural deficit is $0.35 \%$ and that any past deviations accumulate in a "memory account" to be winded down in the future. ${ }^{26}$ Following this surprising restrictive path in the midst of a recession the Stability Pact regulations were significantly tightened in 2011 and in 2012 when 25 EU countries signed an Intergovernmental Treaty, ${ }^{27}$ the so-called Fiscal Compact, introducing stricter rules regarding deficits and debt. A maximum medium-term objective for the structural deficit was set at $0.5 \%(0.35 \%$ in the case of the German law). If we assume that over the very long-term positive and negative output gap effects cancel out, that limit implies a long-term debt ratio well below $20 \%$, considering nominal average growth between 3 and 4\%. This would create acute shortages of safe assets for the financial system that became since the crisis fully collateralised. ${ }^{28}$

Another change was the imposition that any deviation above the $60 \%$ target has to be reduced $5 \%$ per year, on average, over 3 years. Besides being the average level of the time, the other explanation for the $60 \%$ target fixed in the Treaty was the fact

\footnotetext{
${ }^{24}$ See EU Commission (2019).

25 See European Fiscal Board (2019a, 019b).

26 The "debt brake" law was adopted in 2009, revoking the "golden rule" in place since 1969. See Thiele (2015).

27 Treaty on Stability, Coordination and Governance in the Economic and Monetary Union (TSCG).

28 See Gorton and He (2016); see also Gorton and Ordoñez (2014).
} 
that in the long-term the ratio between a 3\% deficit and 5\% nominal growth would converge to a debt to GDP ratio of $60 \%$. The present conditions of secular stagnation, low inflation, and low interest rates destroy the economic rationale for such numbers.

The definition of a long-term target for the debt ratio to GDP is fraught with difficulties. There is no theoretical basis for any particular level. Regarding a rule for the deficit, the proper concept is the cyclically adjusted balance, which is very difficult to calculate with precision, is subject to significant revisions as the measure of the output gap is also frequently revised. It is, therefore, subject to bitter discussions with member countries on approval and compliance. Another quality of a good quantitative fiscal rule is that it should change with some contingencies, namely when monetary policy is constrained by the effective lower bound of interest rates. ${ }^{29}$ This feature is missing in the European Rule.

All these problems led some economists to despair of finding well designed quantitative fiscal rules capable of accommodating different objectives and contingencies. Eichengreen and Wyplocz (2016) go as far as proposing renationalisation of fiscal policy, as they maintain that fiscal spillovers among countries are small, a view that others dispute. ${ }^{30}$ That change would give more responsibility to member states in facing markets because it would be accompanied by a credible no-bailout rule and the increased possibility of debt restructuring. We saw, however, how this worked in 2010-2015.

In the same vein, Blanchard et al. $(2019)^{31}$ recently presented a preliminary version of a proposal that would abolish all the existent quantitative goals, substituting them by guiding principles or standards that would be enforced by the EU Commission in a more discretionary way. The Commission would also have the possibility of taking countries before the European Court of Justice in case of non-compliance. The whole proposal would require a Treaty change, which makes it very difficult to be implemented.

Nevertheless, these are intriguing proposals that deserve some reflection and debate in view of all problems with the implementation of the Pact over the years. ${ }^{32}$ However, I would prefer a two-pronged approach to revise the European fiscal rule, thinking mostly from the perspective of the euro area requirements. On the one hand, the Stability Pact should be revised along the lines of an expenditure growth rule without a formulaic annual progression towards the long-term target of $60 \%$, keeping the 3\% Treaty limit for the nominal deficit but abandoning targets for the structural balance. One advantage of this new rule is that it could be approved without a Treaty change. On the other hand, a European Stabilisation Fund would be

\footnotetext{
${ }^{29}$ See a theoretical background for that possible discussion in Portes and Lewis (2015).

30 This is confirmed in the recent ECB wp by Attinasi and Vetlov (2017); For a different view see Blanchard and Lindé (2017).

31 See Blanchard and Zettelmeyer (2019).

32 On a thorough assessment of the way the Pact has worked see the European Fiscal Board Report (2019).
} 
created to deal with significant asymmetric or symmetric recessionary shocks that cannot be easily accommodated by an expenditure fiscal rule.

Four additional features should be included in the expenditure rule:

- The expenditures considered would be net of interest payments, unemployment subsidies and increases in revenues due to discretionary changes in taxation.

- The annual target for expenditure growth would depend on a medium-term projection of nominal potential growth and the judgemental conclusion about the convergence for the long-term debt ratio target.

- The judgement involved in that component would take in consideration a broader debt sustainability analysis and the short-term situation of the economy.

- National Fiscal Councils would prepare the projections for potential growth over the medium term.

This last point is an important difference from the proposal made in a Note of the French Conseil D'Analyse Économique ${ }^{33}$ that would give the power to the national Fiscals Councils to decide on the annual target for the expenditure ceiling. Such delegitimisation of national Governments and Parliaments in fiscal matters goes too far... It is preferable to continue to subject the national budgets to the European Semester procedures already in place. Another version of an expenditure rule was also proposed by the European Fiscal Board, introducing, however, an even stricter annual reduction in the debt ratio that makes it unacceptable. ${ }^{34}$

Regarding enforcement, market discipline has been reinforced by two significant changes adopted by the last December Summit. First, the introduction of "single limb" clauses in sovereign debt issuance that generalises to all debt instruments what would be decided about one of its components in the context of a debt restructuring. The second was a change in the regime regarding the debt sustainability analysis (DSA) mandatory before any ESM programme decision. This DSA changed from being the sole responsibility of the independent EU Commission to become a cooperative exercise with the ESM, a purely intergovernmental body.

An expenditure rule is much less procyclical than the present regime. Still, it cannot deal efficiently with significant temporary recessionary shocks and does not offer a solution if some member states do not want to use the fiscal space they have. For this purpose, it is necessary to create a European Stabilisation Fund. The IMF made a good proposal to design it. ${ }^{35}$ For periods of quite significant shocks, it takes the form of a "rainy-day" fund with borrowing capacity that would provide transfers to be used in public spending with high multipliers. Transfers should not permanently benefit the same countries, so a cap would be introduced, and, to avoid moral hazard, the use of the Fund should be conditional on past compliance by countries with the existent fiscal rules. Triggering the transfers should be automatically dependent on a threshold indicator based on significant changes in the unemployment rate.

\footnotetext{
33 See Darvas and Ragot (2018).

34 See European Fiscal Board (2019a, b).

35 See Arnold et al. (2018).
} 
The two reforms proposed are crucial to make the space of the European monetary union a truly integrated economic area disposing of an appropriate macroeconomic stabilisation framework. Without this stabilisation function, monetary union can always be subject to disruptive shocks and potential dangerous fragmentation. These possibilities have become evident with the present crisis and forced the suspension of the Stability Pact for an undefined period. Its current inadequacy adds to the arguments to proceed with its revision.

The return of fiscal policy to the frontline of economic thinking offers a favourable conceptual background to get right a revised European fiscal framework.

\section{References}

Agarwal, R. and M. Kimball. 2019. Enabling Deep Negative Rates to Fight Recessions: A Guide. IMF wp 19/84, April.

Arnold, N., Bergljot Barkbu, Elif Ture, Hou Wang, and Jiaxiong Yao. 2018. A Central Fiscal Stabilization Capacity for the Euro Area. IMF SDN/18/03.

Attinasi, M.-G., M. Lalik, and I. Vetlov. 2017. Fiscal Spillovers in the Euro Area, a Model Based Analysis. ECB wp n. 2040, March 2017.

Auerbach, A.J., and Y. Gorodnichenko. 2012. Fiscal Multipliers in Recession and Expansion. Fiscal Policy After the Financial Crisis. National Bureau of Economic Research, pp. 63-98.

Auerbach, A.J., and Y. Gorodnichenko. 2017. Fiscal Stimulus and Fiscal Sustainability. Federal Reserve Bank of Kansas City Symposium, Jackson Hole.

Barro, Robert. 1974. Are Government Bonds Net Wealth. Journal of Political Economy 82(6): 1095-1117.

Barro, R.J. 1979. On the Determination of Public Debt. Journal of Political Economy 87: 940-971.

Bartsch, E., J. Boivin, S. Fisher, and P. Hilodebrand. 2019. Dealing with the Next Downturn: From Unconventional Monetary Policy to Unprecedented Policy Coordination. Taipei: Blackrock Investment Institute.

Begnigno, P., and M. Woodford. 2004. Optimal Monetary and Fiscal Policy: A Linear-Quadratic Approach. NBER wp n. 9905.

Bernanke, B. 2003. Some Thoughts on Monetary Policy in Japan. Speech in Tokyo, May.

Bernanke, B. 2016. What Tools Does the Fed have Left? Part 3: Helicopter money. Brookings blog at https://www.brookings.edu/blog/ben-bernanke/2016/04/11/what-tools-does-the-fed-have-left-part3-helicopter-money/. Accessed 2 July 2020.

Blanchard, O. 2019. Public Debt and Low Interest Rates. American Economy Review 109: 1197-1229.

Blanchard, O., C.J. Erceg, and J. Lindé. 2017. Jump-Starting the Euro Area Recovery: Would a Rise Fiscal Spending Help the Periphery? NBER Macroeconomics Annual.

Blanchard, O., A. Leandro, and J. Zettelmeyer. 2019. Revisiting the EU Fiscal Rules in an Era of Low Interest Rates. Slide presentation at the Law and Macro Conference, Georgetown Law.

Blanchard, O.J., and D. Leigh. 2013. Growth Forecast Errors and Fiscal Multipliers. IMF wp n.1.

Blanchard, O., and L. Summers. 1986. Hysteresis and the European Unemployment Problem. NBER Macroeconomics Annual, vol. 1.

Brand, C., and F. Mazeli. 2019. Taylor-Rule Consistent Estimates of the Natural Rate of interest. ECB wp n. 2257.

Calmfors, L., and S. Wren-Lewis. 2011. What Should Fiscal Councils Do? Economic Policy 26: 5.

Canzoneri, M., R. Cumby, and B. Diba. 2007. Euler Equations and Money Market Interest Rates: A Challenge for Monetary Policy Models. Journal of Monetary Economics 54: 1863-1881.

Carroll, Christopher D. 2001. Death to the Log-Linearized Consumption Euler Equation! (And Very Poor Health to the Second-Order Approximation). Advances in Macroeconomics 1(1), Article 6. http:// www.bepress.com/bejm/advances/vol1/iss1/art6. 
Christiano, L., M. Eichenbaum, and C.L. Evans. 2011. Nominal Rigidities and the Dynamic Effects of a Shock to Monetary Policy. Journal of Political Economy 113(1): 1-45.

Coenen, G., C.J. Erceg, C. Freedman, D. Furceri, M. Kumhof, R. Lalonde, D. Laxton, J. Linde, A. Mourougane, D. Muir, S. Mursula, C. de Resende, J. Roberts, W. Roeger, St Snudden, M. Trabandt, and J. In't Veld. 2012. Effects of Fiscal Stimulus in Structural Models. American Economic Journal: Macroeconomics 4(1): 22-68.

Constâncio, Vítor. 2016. The Challenges of Low Interest Rates and Monetary Policy, pp. 3-4. https:// www.ecb.europa.eu/press/key/date/2016/html/sp160615.en.html. Accessed 2 July 2020.

Darvas, Z., Philippe Martin, and Xavier Ragot. 2018. European Fiscal Rules Require a Major Overhaul. Conseil D’Analyse Économique, Note n. 47 at http://www.cae-eco.fr/IMG/pdf/cae-note047v3.pdf. See also Chapter 16 of the CEPR ebook. "Risk Sharing Plus Market Discipline: A New Paradigm for Euro Area Reform? A Debate".

DeLong, B., and L. Summers. 2012. Fiscal Policy in a Depressed Economy. Brookings Papers on Economic Activity, Spring 2012.

Eichengreen, B., and C. Wyplocz. 2016. Minimal Conditions for the Survival of the Euro. In VoxEU ebook "How to fix Europe's monetary union: Views of leading economists". CEPR Press.

EU Commission. 2019. Vade Mecum on the Stability and Growth Pact. https://ec.europa.eu/info/sites/ info/files/economy-finance/ip101_en.pdf. Accessed 2 July 2020.

European Fiscal Board. 2019a. Reforming the EU fiscal framework: A proposal by the European Fiscal Board. Chapter 17 of the CEPR ebook "Risk Sharing Plus Market Discipline: A New Paradigm for Euro Area Reform? A Debate".

European Fiscal Board. 2019b. Reforming the EU fiscal framework: A proposal by the European Fiscal Board. Chapter 17 of the CEPR ebook "Risk Sharing Plus Market Discipline: A New Paradigm for Euro Area Reform? A Debate".

European Fiscal Board Report. 2019. Assessment of EU Fiscal Rules with a Focus on the Six and TwoPack Legislation.

Fatás, A. 2018. Fiscal Policy, Potential Output and the Shifting Goalposts. CEPR DP 13149.

Fatás, A., and L.H. Summers. 2015. The Permanent Effects of Fiscal Consolidations. CEPR DP n. 10902. Friedman, Milton. 1968. The Role of Monetary Policy. AEA Presidential Address.

Gordon, Robert J. 2012. Is U. S. Economic Growth Over? Faltering Innovation Confronts the Six Headwinds. NBER Working Paper 18315.

Gordon, Robert J. 2014. The Demise of U.S. Economic Growth: Restatement, Rebuttal, and Reflections. NBER wp 19895.

Gordon, R.J. 2016. The Rise and Fall of American Growth: The U. S. Standard of Living since the Civil War. Princeton: Princeton University Press.

Gorton, G., and He. 2016. Optimal Monetary Policy in a Collateralized Economy. NBER wp 22599.

Gorton, G., and G. Ordoñez. 2014. Collateral Crises. American Economic Review Papers and Proceedings 102: 101-106.

Hamilton, J.D., E.S. Harris, J. Hatzius, and K.D. West. 2016. The Equilibrium Real Funds Rate: Past, Present, and Future. IMF Economic Review 64: 660-707.

Holston, K., T. Laubach, and J.C. Williams. 2017. Measuring the Natural Rate of Interest: International Trends and Determinants. Journal of International Economics 108: 59-75.

Jan in 't Veld. 2013. Fiscal Consolidations and Spillovers in the Euro Area Periphery and Core. EU Commission Economic Papers n. 506.

John, Muellbauer. 2016. Macroeconomics and Consumption. Oxford Department of Economics wp at https://www.economics.ox.ac.uk/department-of-economics-discussion-paper-series/macroecono mics-and-consumption. Accessed 2 July 2020.

Kaplan, G., and G.L. Violante. 2014. A Model of the Consumption Response to Fiscal Stimulus Payments. Econometrica 82(4): 1199-1239.

Kirsanova, T.-, C. Leith, and S. Wren-Lewis. 2009. Monetary and Fiscal Policy Interaction: The Current Consensus Assignment in the Light of Recent Developments. The Economic Journal 119: 482-496.

Kydland, F.E., and E. Prescott. 1997. Rules Rather than Discretion: The Inconsistency of Optimal Plans. Journal of Political Economy 85(3): 473-492.

Mehrotra, N. 2017. Debt Sustainability in a Low Interest Rate World. Brookings Hutchins Center wp n. 32 .

Mian, A., K. Rao, and A. Sufi. 2013. Household Balance Sheets, Consumption, and the Economic Slump. Quarterly Journal of Economics 128(4): 1687-1726. 
O'Driscoll, Gerad. 1977. The Ricardian Non equivalence Theorem. Journal of Political Economy 85(1): 207.

Portes, J., and S. Wren-Lewis. 2015. Issues in the Design of Fiscal Policy Rules. In The Manchester School, Vol 83, No S3.

Rachel, L., and L. Summers. 2019. On Falling Neutral Real Rates, Fiscal Policy, and the Risk of Secular Stagnation. Brookings Papers on Economic Activity, March.

Ramey, V.A. 2011. Can Government Purchases Stimulate the Economy? Journal of Economic Literature 49(3): 673-685.

Rannenberg, A., C. Schoder, and J. Strasky. 2015. The Macroeconomic Effects of the Euro Area's Fiscal Consolidation 2011-2013: A Simulation-Based Approach. Research Technical Paper 03/RT/2015, Central Bank of Ireland.

Samuelson, Paul. 1948. Economics: An Introductory Analysis, 353. New York: McGraw-Hill.

Summers, L. 2016. The Age of Secular Stagnation: What It Is and What to Do About It. In: Foreign Affairs March/April 2016 issue.

Thiele, A. 2015. The German Way of Curbing Public Debt: The Constitutional Debt Brake and the Fiscal Compact. European Constitutional Law Review 11: 30-54.

Publisher's Note Springer Nature remains neutral with regard to jurisdictional claims in published maps and institutional affiliations. 